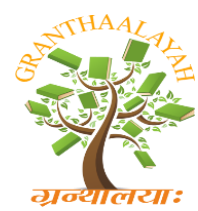

INTERNATIONAL JOURNAL OF RESEARCH GRANTHAALAYAH

A knowledge Repository

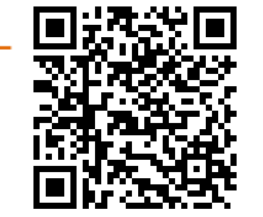

Social

\title{
INFLUENCE OF STUDENTS' GENDER AND STREAM OF STUDY ON SCIENTIFIC ATTITUDE AND ATTITUDE TOWARDS SCIENCE
}

\author{
Swati Gupta ${ }^{* 1}$ \\ ${ }^{* 1}$ Research Scholar, Education Department, AMU, INDIA
}

\begin{abstract}
The present study aims to assess the influence of living place, gender and stream of study on scientific attitude and attitude towards science of higher secondary level students. The study was conducted on a sample of 200 higher secondary students of district Badaun (Uttar Pradesh). Attitude towards Science was assessed by employing the Scale (ATSS) developed by Pandey and Singh (2002) and Scientific Attitude was measured by the scale (SAS) constructed by Gohit and Sreedevi (2008). The findings of the study reveal that gender does not affect the scientific attitude and attitude of students towards science while stream of study plays significant role in determining the scientific attitude and attitude of students towards science.
\end{abstract}

Keywords:

Scientific Attitude, Attitude towards Science, Gender \& Stream of Study.

Cite This Article: Swati Gupta, "INFLUENCE OF STUDENTS' GENDER AND STREAM OF STUDY ON SCIENTIFIC ATTITUDE AND ATTITUDE TOWARDS SCIENCE" International Journal of Research - Granthaalayah, Vol. 3, No. 12(2015): 187-194.

\section{INTRODUCTION}

The progress of a nation depends upon the intellectual capacity of its citizens. Development from the Stone Age to the Space Age was possible only due to the extraordinary abilities of man. The demand of high level ability is also increasing in almost every field of endeavours, which results in the need of innovative and scientific individuals. Therefore, it is necessary to identify the hidden talents of children and provide them suitable environment and education to develop their innate potentialities in the direction of higher achievement (Kothari Commission, 1964-66). Scientific attitude of individuals as well as scientific and technological inventions play important role in the progress of a nation. Science is a basic part of human experience and has relevance for everyone. We are living in the modern era of science where technologies are found in every aspect of life: not only in daily life but also in the research center, in defensive measures of a country and biological aspects etc. No nation could generate the progress unless it promotes technical aspects in diverse fields. Scientific attitude and attitude towards science are essential prerequisites in the pursuit of high status and well paid jobs in a technologically advanced workforce. 
Attitude is directly related with behavior, guides and directs an individual's behavior (Mehrens \& Lehman, 1969; Gupta \& Jan, 2013). The attitude towards science is an internal feeling, gained by the experiences of scientific development and other aspects of science. It indicates feelings of an individual or a group concerning science objects, science policy, science like faith in scientific methods, opinion about scientific inventions, opinion held about science related social issues or identifiable aspects related to science of the environment (Jan \& Gupta, 2014). Scientific attitude can be defined as open-mindedness, a desire for accurate knowledge, confidence in procedure for seeking knowledge and the expectation that the solution of the problems will come through the use of verified knowledge (Jan \& Gupta, 2014).

It is generally believed that attitude plays a vital role in the all-round development of individuals (Gupta \& Jan, 2013). Therefore, one of the goals of education is to develop scientific attitude or scientific outlook towards life style in an individual. It has been felt that ultimate development should result in the formation of right attitude so that an individual can function effectively in a system to improve the system. Therefore, the present study is an attempt to find out the effect of gender and stream of study on scientific attitude and attitude towards science of higher secondary level students.

\section{OBJECTIVES}

The present study has been designed to achieve the following objectives:

1) To compare the scientific attitude of higher secondary students with reference to gender (Male/Female)

2) To compare the attitude of higher secondary students towards science with reference to gender (Male/Female)

3) To compare the scientific attitude of higher secondary students with reference to stream of study (science/non-science)

4) To compare the attitude of higher secondary students towards science with reference to stream of study (science/non-science)

\section{HYPOTHESES}

1) There is no significant difference in the scientific attitude of higher secondary students with reference to gender (Male/Female).

2) There is no significant difference in the attitude of higher secondary students towards science with reference to gender (Male/Female).

3) There is no significant difference in the scientific attitude of higher secondary students with reference to stream of study (science/non-science).

4) There is no significant difference in the attitude of higher secondary students towards science with reference to stream of study (science/non-science).

\section{RESEARCH METHODOLOGY}

In the present study, descriptive survey method was used to assess the influence of gender and stream of study on attitude towards science and scientific attitude of higher secondary students. 
The population was defined as XI class students of C.B.S.E. schools of district Badaun (Uttar Pradesh). Firstly, schools were selected by employing random sampling technique then the students were selected from the chosen schools through cluster sampling technique. A sample of 200 students was finalized for the study. To measure the attitude of higher secondary students towards science, the scale constructed by Pandey and Singh (2002) was used by the investigator. The scale consists of 48 statements. Out of 48 statements, 25 statements are positive and 23 statements are negative. The reliability of the scale is 0.83 and validity is 0.67 . Scientific attitude of the sample was assessed by using Scientific Attitude Scale originally constructed by Gohit and Sreedevi (2008). The scale consists of 36 statements, out of which 18 are positive and 18 are negative. The reliability of the scale ensured by using test-retest method is 0.65 and validity of the scale established by using Pearson correlation between dimensions and total score is from 0.62 to 0.82 . After collecting the data, the results were drawn with the help of SPSS.

\section{RESULTS \& DISCUSSION}

The following tables and subsequent interpretation present a detailed description of the analysis.

Objective 1: To compare the scientific attitude of higher secondary students with reference to gender (Male/Female)

To find out gender difference in scientific attitude of higher secondary students, the inferential statistics ' $\mathrm{t}$ ' test for two independent samples was applied. The result of t-test is shown through below given table (1)

Table 1: Descriptive Statistics related to scientific attitude of Higher Secondary Students according to gender

\begin{tabular}{|l|l|l|l|l|l|}
\hline Sample & $\mathbf{N}$ & Mean & s.d. & 't' Value & Sig. \\
\hline Boys & 100 & 142.98 & 19.54 & \multirow{2}{*}{0.908} & Not Sig. \\
\hline Girls & 100 & 140.60 & 17.42 & & \\
\hline
\end{tabular}

The above given table (1) reveals that mean score of boys is 142.98 with s.d. 19.54 and of girls is 140.60 with s.d. 17.42 . The obtained ' $t$ ' value $(0.908, \mathrm{P}>0.01)$ is not significant at 0.01 level, which indicates that there is no significant difference in scientific attitude of boys and girls studying at higher secondary level. The figure (1) given below clearly depicts the picture of mean scores of boys and girls on the variable 'scientific attitude'. 


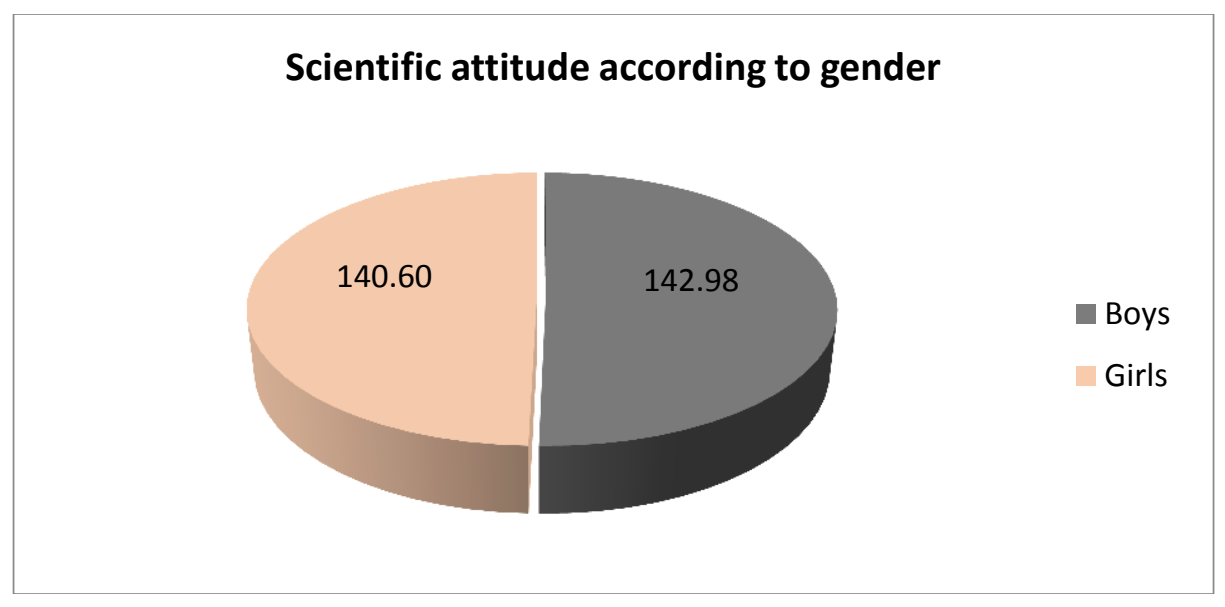

Figure 1: Scientific Attitude of Higher Secondary Students according to Gender

Objective 2: To compare the attitude of higher secondary students towards science with reference to gender (Male/Female)

To study gender difference in attitude towards science of higher secondary students, the inferential statistics ' $t$ ' test for two independent samples was applied. The result of t-test is shown through below given table (2)

Table 2: Descriptive Statistics related to attitude towards science of Higher Secondary Students according to gender

\begin{tabular}{|l|l|l|l|l|l|}
\hline Sample & N & Mean & s.d. & 't' Value & Sig. \\
\hline Boys & 100 & 165.61 & 31.16 & & 0.004 \\
\hline Girls & 100 & 165.59 & 27.29 & Not Sig. \\
\hline
\end{tabular}

It is clear from the above given table (2) that mean score of boys is 165.61 with s.d. 31.16 and of girls is 165.59 with s.d. 27.29 , which are approximately equal. The obtained ' $t$ ' value $(0.004$, $\mathrm{P}>0.01$ ) is also not significant at 0.01 level, which indicates that there is no significant difference in attitude towards science of boys and girls studying at higher secondary level. The figure (2) given below clearly depicts the picture of mean scores of boys and girls on the variable 'attitude towards science'. 


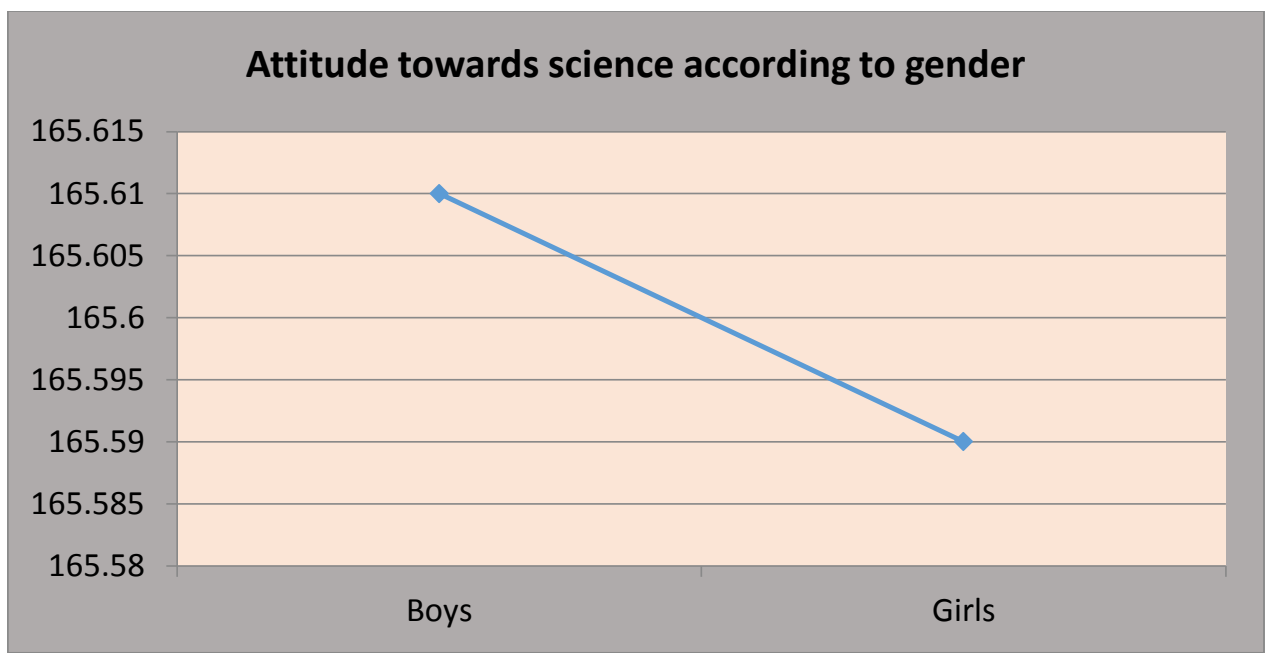

Figure 2: Attitude of Higher Secondary Students towards Science according to Gender

Objective 3: To compare the scientific attitude of higher secondary students with reference to stream of study (science/non-science)

In order to assess the difference in scientific attitude of higher secondary school students with reference to stream of study, ' $t$ ' test was applied. The result of t-test is presented in below given table (3).

Table 3: Descriptive Statistics related to scientific attitude of higher secondary students according to stream of study

\begin{tabular}{|l|l|l|l|l|l|}
\hline Sample & N & Mean & s.d. & 't' Value & Sig. Level \\
\hline Science & 100 & 155.11 & 10.34 & 14.62 & 0.01 \\
\hline Non-Science & 100 & 128.51 & 14.36 & & \\
\hline
\end{tabular}

A perusal of above given table reveals that the mean score of higher secondary school students belonging to science stream is 155.11 with s.d. 10.34 while the mean score of their counterparts belonging to non-science stream is 128.51 with s.d. 14.36 . The calculated ' $t$ ' value (14.62, $\mathrm{P}<0.01)$ is significant at 0.01 level of significance. It indicates that there is significant difference between the scientific attitudes of higher secondary school students with reference to stream of study. The mean score of higher secondary school students belonging to science stream is higher, which confirms that science students studying at higher secondary level possess higher scientific attitude than their counterparts of non-science stream. The mean difference of science and nonscience students in scientific attitude is shown graphically in figure 3 . 


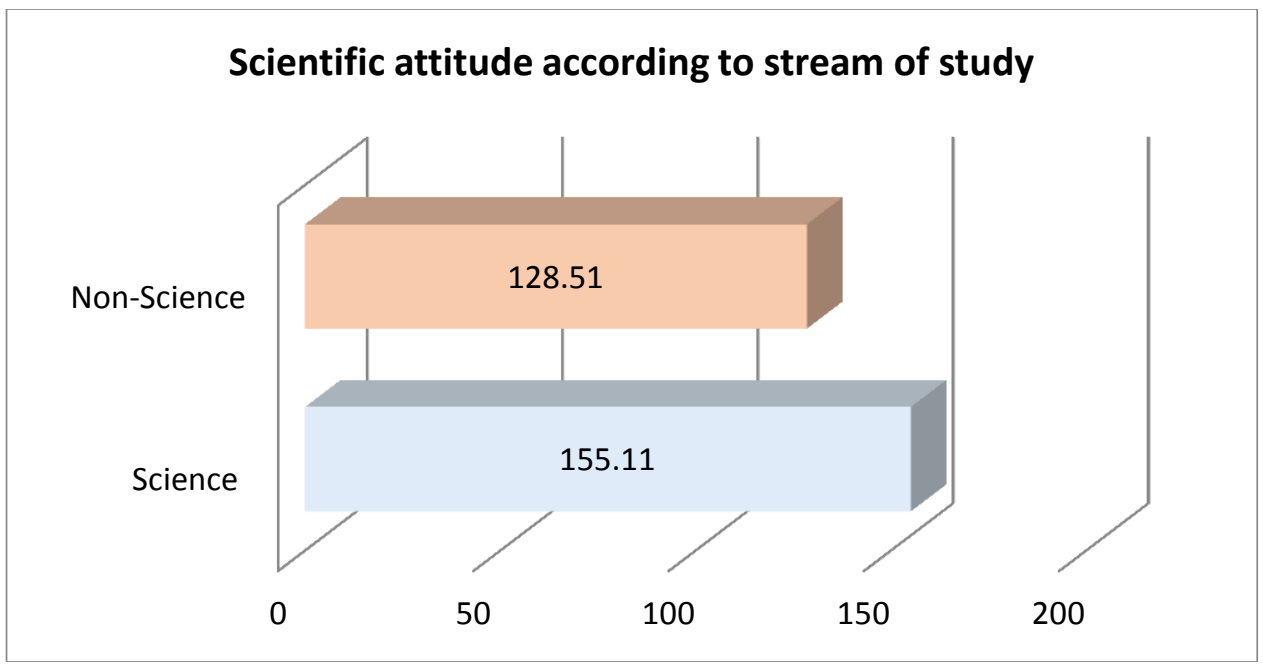

Figure 3: Scientific Attitude of Higher Secondary Students according to Stream of Study

Objective 4: To compare the attitude of higher secondary students towards science with reference to stream of study (science/non-science)

In order to know the difference in attitude towards science of higher secondary school students with reference to stream of study, ' $t$ ' test was applied. The result of t-test is presented in below given table (4).

Table 4: Descriptive Statistics related to attitude towards science of Higher Secondary Students according to stream of study

\begin{tabular}{|l|l|l|l|l|l|}
\hline Sample & $\mathbf{N}$ & Mean & s.d. & 't' Value & Sig. Level \\
\hline Science & 100 & 189.84 & 14.53 & 21.20 & 0.01 \\
\hline Non-Science & 100 & 141.27 & 17.71 & & \\
\hline
\end{tabular}

A perusal of above given table reveals that the mean score of higher secondary school students belonging to science stream is 189.84 with s.d. 14.53 while the mean score of their counterparts belonging to non-science stream is 141.27 with s.d. 17.71. The calculated ' $t$ ' value (21.20, $\mathrm{P}<0.01)$ is significant at 0.01 level of significance. It indicates that there is significant difference between attitudes of higher secondary school students towards science with reference to stream of study. The mean score of secondary school students belonging to science stream is higher, which confirms that science students studying at higher secondary level possess higher attitude towards science than their counterparts of non-science stream. The mean difference of science and non-science students in attitude towards science is presented graphically in figure 3. 


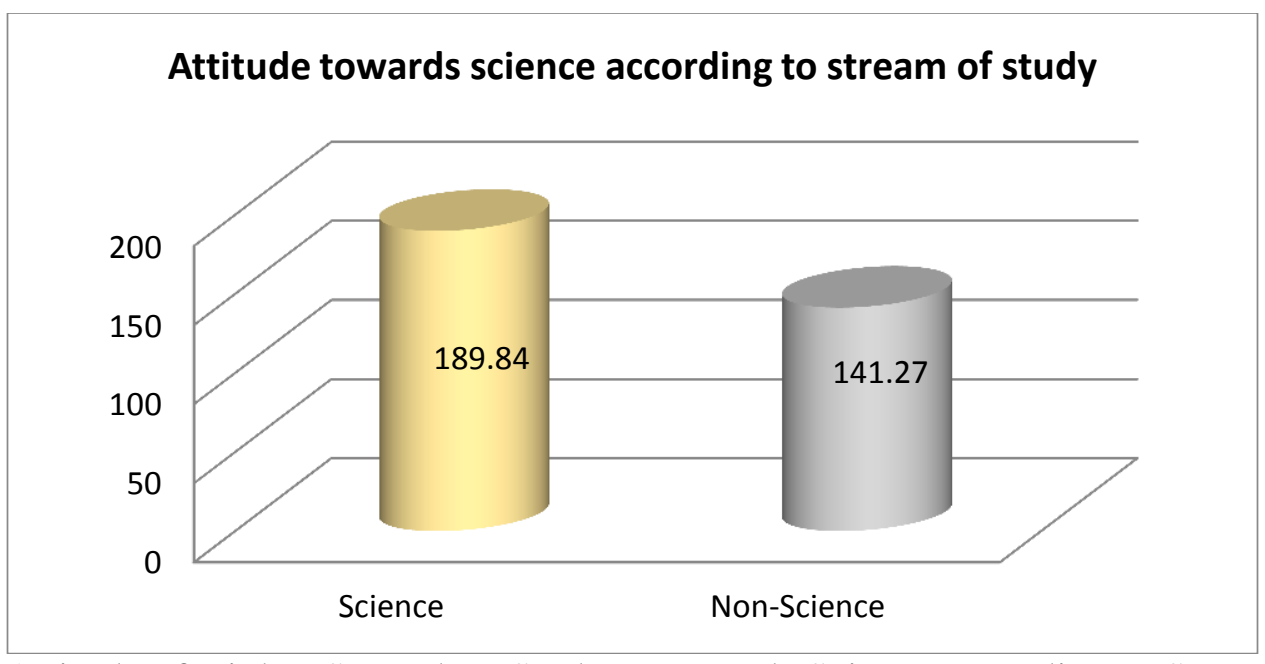

Figure 4: Attitude of Higher Secondary Students towards Science according to Stream of Study

\section{CONCLUSION}

- There is no significant effect of gender in determining the scientific attitude of higher secondary level students.

- Gender does not play any significant role in determining the attitude towards science of higher secondary level students.

- Stream of study causes significant effect in determining scientific attitude of higher secondary level students. Science students have more favourable scientific attitude in comparison to their counterparts of non-science stream.

- Stream of study also plays significant role in determining the attitude of higher secondary level students towards science. Science students have more favourable attitude towards science than non-science students.

\section{DISCUSSION}

A balanced and healthy home discipline aims at preparing children for self-control and self confidence. The democratic environment at home makes the child emotionally controlled and enables him to develop the ability to manage the affairs independently without the necessitating the constant supervision of an adult authority. Thus a balanced democratic environment can develop more scientific attitude and attitude towards science. The study is also beneficial for teachers and school administrators also. They should make the classroom a pleasant, attractive and comfortable place to develop favourable attitude towards science. School administrators should provide well-equipped laboratories so that an atmosphere of enquiry and investigation involving analytic thinking can prevail during teaching. Special counselling cells should be established for helping students and teachers in identifying their scientific attitude and attitude towards science. The syllabus of natural sciences throughout the secondary classes should be revised in a manner so as to ensure that most of the topics included are actively linked to experiments and activities that can be performed by the students and teachers. 


\section{REFERENCES}

[1] Alexander, B. (1990). The Influence of Critical Thinking, Science Aptitude and SES and Achievement in Science in J.P. Sharma (Ed.). Fifth Survey of Research in Education, vol. I, New Delhi, N. C. E. R. T. Publication P- 360.

[2] Allport, G.W. (1935). Attitude Theory and Measurement. New York: John Willy and Sons, $1-13$.

[3] Gohit, R. K. \& Sreedevi, K.V. (2008). Scientific Attitude Scale, Constructivism in Science Education. Discovery Publishing House.

[4] Guilford, J.P. (1978). Fundamental Statistics in Psychology and Education. McGraw Hill Book Corporation, New York.

[5] Gupta, N.K. (1997). Research in Teaching of Science. APH Publishing Corporation, Mumbai.

[6] Gupta, S. \& Jan, A. (2013). Attitude of B.Ed. Pupil-Teachers of Science and Arts Streams towards Creative Teaching: A Study. International Journal of Advancement in Education and Social Sciences, ISSN: 2322-0023, Vol. 1 (1), pp. 36-41.

[7] Jan, A. \& Gupta, S. (2014). The Effect of Scientific Attitude and Attitude towards Science on Academic Achievement in Science at Higher Secondary Level. Naval Shodh: An International Research Journal of Humanities and Social Sciences, ISSN: 2394-3556, Vol. 1, pp. 85-94.

[8] Kerlinger, F.N. (1983). Foundations of Behavioural Research. New York: Holt, Rinehart and Winston.

[9] Kothari, D.S. (1966). Report of the Education Commission 1964-66. New Delhi: Govt. of India.

[10] Mahrens, W.A. \& Lehman I. J. (1969). Standardized Test in Education. New York: Holt, Rinehart and Winston.

[11] Malviya, D.S. (1991). A Study of Attitude towards Science and Interest in Science of School Going Adolescents. Ph.D. Dissertation, Rani Durgawati Vishwavidyalaya, Jabalpur.

[12] Mangal, S.K. (1992). Teaching of Science (2 ${ }^{\text {nd }}$ ed.). New Delhi, Arya Book Depot, Karol Bagh.

[13] Pandey, N.N. and Y.P. Singh (2002). Attitude towards Science Scale. Department of Education \& Allied Sciences, M.J.P. Rohilkhand University, Bareilly.

[14] Vaidya, N. (1999). Science Teaching for the $21^{\text {st }}$ Century. Deep \& Deep Publication pvt. Ltd., New Delhi. 